\title{
CHRONIC EFFECT OF VAGOTOMY IN THE MORPHOMETRY OF THE MYENTERIC PLEXUS OF RATS' DUODENUM
}

\author{
Efeito crônico da vagotomia sobre a morfometria do plexo mioentérico do duodeno de ratos \\ Carlos Roberto MARTINS-JÚNIOR ${ }^{1}$, Aezio de MAGALHÃES-JÚNIOR ${ }^{1}$, Paola Mayumi INAGAKI ${ }^{1}$, \\ Pedro Paulo PIRES ${ }^{2}$, João José LACHAT $^{3}$, Jesiel Mamedes SILVA ${ }^{4}$
}

From the ${ }^{1}$ Federal University of Mato Grosso do Sul, Campo Grande, MS; ${ }^{2}$ Microscopy Laboratory - EMBRAPA, Campo Grande, MS; ${ }^{3}$ Anatomy and Surgery Department, Medicine School of Ribeirão Preto, Universidade de São Paulo, Ribeirão Preto, $\mathrm{SP} ;{ }^{4}$ Morphophysiology Department - CCBS - Federal University of Mato Grosso do Sul, Campo Grande, MS, Brazil.

HEADINGS: Autonomic denervation. Auerbach's nervous plexus. Morphology.

\section{Correspondência:}

Jesiel Mamedes Silva,

email: jemsilva@umfs.br

Fonte de financiamento: não há

Conflito de interesses: não há

Recebido para publicação: 03/05/2010

Aceito para publicação: 14/06/2010

DESCRITORES - Desnervação autonômica. Plexo nervoso mioentérico de Auerbach. Morfologia.
ABSTRACT - Background - The gastrointestinal disorders have been associated with morphological alterations in the myenteric nervous plexus. Aim - To evaluate, through morphometric studies, the chronic effects of the subdiaphragmatic trunk vagotomy on the nervous plexus. Methods Fifteen male exemplars of Wistar Rattus novergicus weighing about $150 \mathrm{~g}$, distributed into three groups, have been used: control $(n=5)$, Sham $(n=5)$ and vagotomized $(n=5)$. The animals were sacrificed after 30 and 90 days post surgery. Fragments of duodenum were fixed in Bouin solution, embedded into paraffin and stained with $\mathrm{HE}$ and PAS. Morphometric analysis was performed by a Carl Zeiss KM 450 image system. The following aspects were observed: the density of nervous cells per linear micrometer ( $\mu \mathrm{m})(\mathrm{ND})$; the area of perikarya $\left(\mu \mathrm{m}^{2}\right)(\mathrm{NA})$; the number of satellite cells per $\mu \mathrm{m}(\mathrm{SCD})$; and the number of satellite cells per neuron (SC/N). The averages were compared with the help of "software" program Sigma Plus through two way - ANOVA and Tuckey post-test. Results - Denervation increased $S C / N(p<0,05)$ and NA $(p<0,05)$, in a time-dependent denervation way $(p<0,05)$. However ND and SCD, decreased, which significantly with the animal's age $(p<0,001)$. Conclusion -Vagotomy altered the myenteric plexus morphology in a timedependent way.

RESUMO - Racional - As disfunções gastrintestinais têm sido associadas à alterações morfológicas no plexo nervoso mioentérico. Objetivo - Avaliar através do estudo morfométrico, os efeitos crônicos da vagotomia troncular subdiafragmática sobre esse plexo nervoso. Métodos - Foram utilizados 15 exemplares machos de Rattus novergicus da variedade Wistar, com cerca de $150 \mathrm{~g}$, distribuídos nos grupos controle $(n=5)$, Sham $(n=5)$ e vagotomizados $(n=5)$. Os animais foram sacrificados depois de 30 e 90 dias após as operações. Em seguida, fragmentos do duodeno foram fixados em solução de Bouin, incluídos em parafina e corados por HE e PAS. A análise morfométrica foi realizada por meio do sistema de análise de imagem Carl Zeiss KM 450. Foram observados: a densidade de células nervosas por micrômetro linear $(\mu \mathrm{m})$; a área dos pericários $\left(\mu \mathrm{m}^{2}\right)$; o número de células satélites por $\mu \mathrm{m}$; e o número de células satélites por neurônio. As médias foram comparadas com o auxílio do programa de "software" Sigma Plus através do Two way - ANOVA e do pós-teste de Tukey. Resultados - A desnervação aumentou o número de células satélites por neurônios $(p<0,05)$ e a área média dos pericários $(p<0,05)$, de maneira dependente do tempo de desnervação $(p<0,05)$, mas diminuiu significativamente a densidade de neurônios $(p<0,05)$ e de células satélites $(p<0,05)$ em função da idade $(p<0,001)$. Conclusão - A vagotomia alterou a morfologia do plexo mioentérico de maneira dependente do tempo. 
INTRODUCTION

G astrointestinal homeostasis requires the integration of intrinsic and extrinsic luminal signs with intrinsic and extrinsic neuroendocrine system. Seventeen types of neurons were topographically identified and localized in the enteric nervous system according to morphologic and biochemical differences. They may be functionally grouped into primary intrinsic neurons, motoneurons and interneurons, whose anatomic unities of enteric nervous system overlap ${ }^{6}$. According to Kirchgessner and Gershon ${ }^{12}$, the vagal efferent fibers account for one of the intra-enteric routes that perform synapses with the myenteric plexus neurons.

The extrinsic autonomic innervation (EAI) has a trophic effect on the intestinal epithelium, modulates the dynamics of the epithelial cells along the crypt/ vilosity axis and its circadian rhythm ${ }^{14}$, controls the peristaltic movements ${ }^{20}$.

The enteric neurons, in turn, modulates the destination of the stem cells in the Lieberkühn crypts $^{3}$, the proliferation, the cellular migration ${ }^{11}$, and the incidence of apoptosis of epithelial cells along the crypt/vilosity axis ${ }^{17}$. They also regulate the population of enteroendocrine cells ${ }^{19}$ and the proliferation of smooth muscular fibers in the mucosa and in the intestine muscular tunica ${ }^{16}$.

The density of the myenteric neurons and afferent vagal fibers in the small intestine decreases in the oral-aboral direction ${ }^{17,18}$. During the aging process $^{9}$, in diabetes ${ }^{21}$ and Chagas disease ${ }^{1}$, the contingent of these cells is also decreased. In the aging process, this neuronal loss depends on the vagal extrinsic fibers, which suggests that the trophic function of the extrinsic innervation to the enteric neurons ${ }^{19}$. On the other hand, this could be related to the larger susceptibility of the elderly to stresstriggered intestinal disorders ${ }^{4}$.

Moreover, the high level of nitric oxide has been associated with the death of enteric neurons of experimental Chagasic rats $^{8}$ and in extrinsically denervated animals ${ }^{29}$. However the chronic effects of extrinsic autonomic denervation or intestinal resection in the population of myenteric neurons are still unknown. On the other hand, the enteric glial cells control the destination of the stem cells of Lieberkhünn crypts $^{16}$ and the intestinal homeostasis by cells of $\mathrm{Cajal}^{2}$. Little is known, however, about the influence of vagotomy on these cells.

The experimental method of surgical denervation poses an accessible and interesting model of study about the role of extrinsic innervation in vivo $^{7}$ and chronic stress ${ }^{5}$.

This study intents to analyze, by the histochemical method $\mathrm{HE}$, the chronic effect of subdiaphragmatic trunk surgical vagotomy on the number of satellite and ganglion cells in the myenteric nervous plexus of Wistar rats' duodenum.

\section{METHODS}

Thirty Rattus norvegicus, male, young, from the Wistar variety have been used. They came from the animal house of Universidade Federal do Mato Grosso do Sul, and had a body weight of $144 \pm 28,3$ grams. During the whole experiment, the animals were kept in cages with up to five exemplars; receive unrestricted tap water and commercial ration; and were kept under temperature of $27^{\circ} \mathrm{C}$, photoperiod of 12 hours and air humidity between 40 and $50 \%$. During the experimental development, regulations were followed according to Colégio Brasileiro de Experimentação Animal (COBEA).

The animals were distributed into control group (with no surgery) $(n=5)$, "Sham" $(n=5)$, which underwent simulation surgery, and the vagotomized group $(n=5)$. The surgeries occurred between $9 \mathrm{am}$ and $1 \mathrm{pm}$. The simulation surgery involved laparotomy for visualizing the vagal trunks. Thirty and 90 days after the operation, the animals were anesthetized and had their heads removed and dissected for material collection .

Vagotomy was performed at subdiaphragmatic level, involving front (right) and back (left) vagal trunk, which were resected along the esophagus immediately before its ramifications. The visualization of the vagal back trunk was facilitated by the withdrawal of the hepatic lobes ligaments, and by a soft stomach traction in the skull-caudal direction, followed by a $180^{\circ}$ turn rightwards. Soon after visualization, a $1 \mathrm{~cm}$ resection was performed, just above the emergence of the pair of celiac nerves. The animals presenting peritonitis, cachexia and ill physical condition have been discarded and replaced.

Fragments of approximately $1 \mathrm{~cm}$ have been extracted from the duodenum, $1 \mathrm{~cm}$ far from the pyloric valve. The samples were opened along their mesenteric margin, printed on office paper $150 \mathrm{~g} / \mathrm{m}^{2}$, painted with Bouin solution and kept in a flask with the same solution. After 30 minutes, they were cut rectangularly, so as to facilitate the longitudinal orientation. Next, the samples were kept in Bouin solution for 48 hours for concluding the fixation process. The $6 \mu \mathrm{m}$-thick sections were stained with HE and PAS-Hematoxylin for glycoconjugates.

Morphometry was performed by a Carl Zeiss KM 450 image system. Observations were performed in six $1-\mathrm{cm}$ longitudinal sections obtained from different heights of duodenum. Each animal was submitted to ten consecutive counting of 30 neurons of myenteric plexus, whose distance in micrometers $(\mu \mathrm{m})$ was considered for the calculus of cell density of neurons and satellite cells.

The following aspects were observed: the density of nerve cells per linear micrometer (ND); the perikarya 
area $\left(\mu \mathrm{m}^{2}\right)(\mathrm{NA})$, the density of satellite cells per linear $\mu \mathrm{m}(\mathrm{SCD})$, and the number of satellite cells per neuron $(\mathrm{SC} / \mathrm{N})$. On assessing the last parameter, only the glial cells visualized close $(100 \mu \mathrm{m})$ to the perikarion of ganglional neuron were considered. The averages were compared with "software" program Sigma-Plus by Two way - ANOVA and by Tuckey test. Differences with $p<0,05$ were considered significant.

\section{RESULTS}

Vagotomy did no alter the density of neurons per linear micrometer (ND), which tended to decrease between 60 and 120 days of age, or 30 and 90 days after operation. This could be a physiological adaptation of the normal myenteric plexus because of age.

The surgeries influenced the relation between the numbers of satellite cells and neurons $(C S / N)(p=0,002)$. However, no alteration was seen in relation to the time of surgery. Surgical stress tented to increase SC/N, whose effect was significant 90 days post vagotomy $(p<0,05)$.

On the other hand, the density of satellite cells per linear micrometer $(S C D)$, varied significantly with the time of treatment $(p<0,001)$. Although no significant variations have been seen between the surgeries, the results depended on time $(p=0,007)$. On the first thirty days post surgery, the satellite cells tended to increase, and then decreased after ninety days in all treatments $(p<0,05)$.

Surgical stress increased in the mean area of the neuron perikarya (NA) $(p=<0,001)$, in a time-dependent way $(p=<0,001)$ and proportional to the level of stress involved in the surgery. On the first thirty days, there was the effect of laparotomy on NA $(p<0,05)$, but it was smaller than the vagotomy effect $(p<0,05)$. Even after 90 days, although the denervation effect has decreased, it was different from the other treatments $(p<0,05)$.

\section{DISCUSSION}

The results seen here enhanced the influence of the surgical stress and extrinsic innervation on the morphology of myenteric nervous plexus. Vagotomy and surgical stress increase the volume of nervous cells, which was also observed by Tafuri ${ }^{22}$. This factor masked the reduction of these cells in number, provoked by denervation. The dilatation of small intestine and the hypertrophy of chagasic colon occur when there is reduction of more than $55 \%$ of ganglionar cells of enteric nervous system ${ }^{13}$. The confirmation of megastomach and megaintestine in 50\%, and megacolon in $40 \%$ of the denervated animals suggests loss of nervous cells. In the Chagas disease patients, neuronal loss is associated with the increase in size of the nervous cells, which makes necessary the correction factor to quantify the cells ${ }^{1}$. When a similar correction factor $(0,579)$ was applied, a significant reduction of myenteric neurons in density was seen (ND) $(p<0,05)$.

The extrinsic denervation increases in $93 \%$ the nitric oxide synthase expression (NOS) in the enteric neurons ${ }^{29}$. Garcia et al. ${ }^{8}$ associated, in Chagasic animal models, the increase of levels of nitric oxide in enteric neurons with the death of these cells. Alterations in the myenteric plexus have been associated with motility disorders such as slow transit constipation ${ }^{26}$ and changes on morphophysiology of the submucous neurons and cells of $\mathrm{Cajal}^{10}$. Among such alteration lies the decrease of interstitial glial cells ${ }^{2}$. Although the number of satellite cells per neuron has increased during the chronic period of vagotomy (30 to 90 days), the density of satellite glial cells (SCD) has decreased. This alteration could contribute to the gastrointestinal disorders seen after intestinal resection.

Constipation, incontinence and evacuation problems are more common in elderly population. In studies with rats and other models, a decrease of myenteric neurons and glial cells is $\operatorname{seen}^{26}$. It is noteworthy remarking that there is hierarchy in the neuronal myenteric loss during the aging process when the nitrergic are more resistant than the cholinergic neurons ${ }^{25}$. In all animals studied, ND tended to decrease with age, irrespective of treatment, whereas the satellite cells decreased significantly from 30 to 90 days, irrespective of the treatment group. This was not expected, as these animals are still considered young adults. It may be understood as a physiological adaptation or evidence of early aging of these animals' Auerbach nervous plexus.

Nowadays intestinal constipation is known to be associated with extrinsic innervation loss. Emmanuel and $\mathrm{Kamm}^{5}$ confirmed that constipation sufferers, especially with idiopathic constipation, presented with malfunction in the vagal efferent activity, which alters the dynamic of their myenteric cells and neuromuscular malfunction. This is associated to survival of myenteric neurons provoked by blood flow vagotomy alterations.

The relation between the neurons of the myenteric system and the mast cells is dynamic are closely related to the nerve endings and may play the role of a neural retransmitter ${ }^{22}$. On the other hand, the extrinsic innervation of enteric nervous system modulates, via enteric glial cells ${ }^{25}$, the activity and population of mast cells $\mathbf{s}^{15}$. The brain to mast cell connection appears to be a mechanisms that can link psicho-emotional status to irritable states of digestive tract to stress and/ or neurophathics diseases ${ }^{27}$. The overproduction of cytokines produced by the mast cells and glial cells constitutes, therefore, key-elements in determining the trophic "status" of the nervous cells, whose mediators could be the target of interesting medications in the treatment of neuroenteropathies and degenerative diseases. 


\section{CONCLUSION}

Subdiaphragmatic surgical vagotomy showed to be a good method to study the chronic effects of denervation on the morphology of duodenum Auerbach plexus. The denervation increased the number of satellite cells per neuron and the area of perikarya in a time-dependent. Between 30 and 90 days of denervation the number of neurons and satellite cells decreased, whereas the number of satellite cells per neuron and the size of the nervous cells increased. Therefore, during the chronic phase, the vagotomy altered the myenteric plexus morphometry, whose effect depended on the denervation time.

\section{REFERENCES}

1. Adad SJ, Cançado CG, Etchebehere RG, Teixeira VP, Gomes UA, Chapadeiro E, Lopes ER.Neuron count reevaluation in the myenteric plexus of chagasic megacolon after morphometric neuron analysis. Virchows Arch. 2001 Mar;438(3):254-8.

2. Bassotti G, Villanacci V, Maurer CA, Fisogni S, Di Fabio F, Cadei M, Morelli A, Panagiotis T, Cathomas G, Salerni B. The role of glial cells and apoptosis of enteric neurons in the neuropathology of intractable slow transit constipation. Gut. 2006;55:41-46.

3. Bjerknes $\mathrm{M} ;$ Cheng $\mathrm{H}$. Modulation of specific intestinal epithelial progenitors by enteric neurons. Proc Natl Acad Sci U S A. 2001 October 23; 98(22): 12497-12502.

4. Ciccociopo R, DI Sabatino A, Luinetti O, Rossi M, Cifone MG, Corazza GR. Small bowel enterocyte apoptosis and proliferation are increased in the elderly. Gerontol. 2002;48:204-208.

5. Emmanuel AV, Kamm MA. Laser Doppler flowmetry as a measure of extrinsic colonic innervation in functional bowel disease. Gut 2000;46;212-217; doi:10.1136/gut.46.2.212.

6. Furness JB. Types of neurons in the enteric nervous system. J of the Autonc Nerv Syst. 2000;81:87-96.

7. Garcia SB, Kawasaky MC, Silva JCF et al. A new model to increase the intestinal absorptive surface in short-bowel syndrome. J Sur Res. 1999; 85:200-203.

8. Garcia SB, Paula JS, Giovannetti GS, Zenha F, Ramalho ER, Zucoloto $\mathrm{S}$, Silva JS, Cunha FQ. Nitric Oxide Is Involved in the Lesions of the Periphereal Autonomic Neurons Observed in the Acute Phase of Experimental Trypanosoma cruzi Infec Exp Parasitol 1999; 93:191197.

9. Gomes OA, de Souza RR, Liberti EA. A preliminary investigation of the effects of aging on the nerve cell number in the myenteric ganglia of the human colon. Gerontology. 1997;43(4):210-7

10. Hernandes L, Gama P, Alvares EP. IIeal VIP submucous neurons: confocal study of the area enlargement induced by myenteric cells of Cajal in weanling rats. Regul Pept. 2004; 117(1): 69-72.
11. Hernandes L, Zucoloto S, Alvares PE. Effect of myenteric denervation on intestinal epithelium proliferation and migration of suckling and wealing rats. Cell Prolif v. 33, p. 127-138, 2000.

12. Kirchgessner AL, Gershon MD. Identification of vagal efferent fibers and putative target neurons in the enteric nervous system of the rat. J Comp Neurol. 1989; 285:38-53.

13. Köberle F. Chagas disease and chagas syndromes: the pathology of american trypanosomiasis. Adv Parasitol.1968;6:63-116.

14. Lachat JJ, Gonçalves R. Influence of autonomic extrinsic denervation upon the kinetics of the Ileal epithelium of the rat. Cell Tiss Res. 1978; 192:285-297.

15. Moraes OO, Melo DA, Shinzato DH, Silva JM. Chronic effects of autonomic extrinsic denervation on mast cells number in mesenteric tissue of Wistar rats. Neurobiologia 2008; 71(3):51-58.

16. Nelson DW, Sharp JW, Brownfield MS, Raybould HE, Ney DM.Localization and activation of glucagon-like peptide-2 receptors on vagal afferents in the rat. Endocrinology. 2007 May;148(5):1954-62. Epub 2007 Jan 18

17. Noda T, Iwakiri R, Fujimoto $K$, Yoshida T, Utsumi $H$, Sakata $H$, Hisatomi A, Aw TY. Suppression of apoptosis is responsible for increased thickness of intestinal mucosa in streptozotocininduced diabetic rats. : Metabolis 50(3):259-264, 2001.

18. Phillips RJ, Powley TL. As the Gut Ages: timetables for aging of innervation vary by organ in the fischer 344 Rat. J of Comp Neurol. 2001; 434: 358-377.

19. Santos GC, Zucoloto S, Garcia SB. Endocrine cells in the denervated intestine. Int J Exp Path v. 81, p. 265-270, 2000.

20.Scott RB, Tan DT, Miampamba M, Sharkey KA. Anaphylaxisinduced alterations in intestinal motility: role of extrinsic neural pathways. Am J Physiol 1998;275(4):G8 12-21.

21. Souza RR et al., 1993. Age-induced nerve cell loss in the myenteric plexus of the small intestine in man. Gerontol 39:183-188.

22. Stead RH, C, Wang B, Partosoedarso E, Lin J, Stanisz A, Hillsley K. Vagal influences over mast cells. Auton Neurosci 2006;125(12):53-61.

23. Tafuri WL. Light and electron microscope studies of the autonomic nervous system in experimental and human american trypanosomiasis. Virchows Arch. 1971;354:136-149.

24. Thrasivoulou $C$, Soubeyre $V$, Ridha $H$, et al. Reactive oxygen species, dietary restriction and neurotrophic factors in age-related loss of myenteric neurons. Aging Cell 2006;5:247-57.

25. Van der Boyer. Nerve growth factor secretion in cultured enteric glial cells is modulated by proinflammatory cytokines. J. of Neuroendocrinal 2006;18(11):820-825.

26. Wade PR, Cowen T. Neurodegeneration: a key factor in the ageing gut.

27. Wedel T, Roblick UJ, Ott V, Eggers R, Schiedeck TH, Krammer HJ, Bruch HP. Oligoneural hypoganglionosis in patients with idiopathic slow transit constipation. Dis Colon Rectum. 2002;45:54-62.

28. Wood JD, Alpers DH, Andrews PLR. Fundamentals of Neurogastroenterology. Gut 1999; 45(II): II6 - II16.

29. Yunker AM, Galligan JJ. Extrinsic cells of cajal increases myenteric nitric oxide synthase containing neurons and inhibitory neuromuscular transmission in guinea pig. J Auton Nerv Syst. 1998; 15:148-158. 